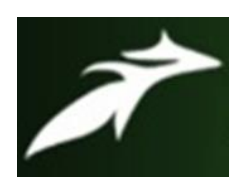

Niranjana Chandran et al, International Journal of Advances in Agricultural Science and Technology,

Vol.7 Issue.11, November-2020, pg. 145-156

ISSN: 2348-1358

Impact Factor: 6.057

NAAS Rating: 3.77

\title{
A STUDY ON THE CHALLENGES FACED BY COFFEE GROWERS OF KANIYAMBETTA PANCHAYAT OF WAYANAD DISTRICT
}

\author{
Niranjana Chandran*, Prabitha P.B** \\ *Assistant Professor (Contract), College of Co-operation, Banking and Management, Kerala Agricultural \\ University, KAU Main Campus, niranjanachandran94@gmail.com, 8281404837. \\ **Research Scholar, College of Co-operation, Banking and Management, Kerala Agricultural University, KAU \\ Main Campus, prabitha36@gmail.com, 7025017106.
}

DOI: 10.47856/IJAAST.2020.v07i11.018

\begin{abstract}
Coffee is the major plantation crop in India and also the widely traded commodity in the international market. Kerala is the second largest coffee producing state in India. The major coffee production in Kerala is from Wayanad district. However, there are many challenges faced by coffee growers in Wayanad. Hence the study aims to evaluating the various challenges faced by coffee growers of Kaniyambetta panchayat of Wayanad district, which is the $2^{\text {nd }}$ highest coffee producing panchayat of Wayanad. The study found that the major problems of coffee growers were related with production and harvesting. Therefore, it is suggested to ensure the supply of quality inputs and harvesting techniques for the growers. Keywords: Coffee production, Challenges, Wayanad district.
\end{abstract}

\section{Introduction}

India is growing as an important player in coffee production at the international level. Major production is concentrated at the southern region of India. Coffee can be considered as the widely traded commodities among the international market 60 percentage of the world's coffee production is from Brazil followed by Vietnam, Columbia and Indonesia (International Coffee Organization, 2018). Coffee is the major plantation crop in India, which is mainly grown under shaded condition. India stands the Asia's $3^{\text {rd }}$ largest producer and exporter of coffee. Coffee shipment from India rose 13.2 $6 \%$ to 48,330 tonnes (Coffee Board, 2018).India's coffee growing regions have diverse climatic conditions, which are well suited for cultivation of different varieties of coffee, some regions with high elevations are ideally suited for growing Arabica and those with mild humid conditions are best suited for Robusta. Karnataka has the highest production about 2, 19,550 (MTs), followed by Kerala and Tamilnadu. Kerala has the production of 2,210 (MTs) Arabica and 68,225 (MTs) of Robusta (Coffee Board, 2018). Kerala contribute $23 \%$ to the total production of Indian coffee economy, in which $58450(\mathrm{MTs})$ is from Wayanad.

During the second half of $19^{\text {th }}$ century coffee cultivation reached at its peak, and then the coffee plantations got collapsed due to the outbreak of pest and diseases also climatic fluctuations and price volatility made distress in the farming community. Price volatility is a major factor that characterizes the Coffee Industry. While it is a global phenomenon with respect to all agricultural commodities, the unpredictable nature of coffee prices makes it difficult for growers to take decisions related to production. Given that vast majority of them are small growers, fluctuating prices also affect their livelihood security. India's coffee sector is in transition in its development phase. Traditionally, most 


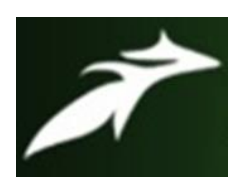

Niranjana Chandran et al, International Journal of Advances in Agricultural Science and Technology,

Vol.7 Issue.11, November-2020, pg. 145-156

ISSN: 2348-1358

Impact Factor: 6.057

NAAS Rating: 3.77

of the coffee produced was marketed by the Indian Coffee Board as raw coffee in the low-value segment that was blended with coffee from other countries (India micro finance.com).

\section{Statement of the Problem}

Coffee is an agro based rural industry; it plays an important role in the development of the country. The industry is driven by the enterprise of around 280,241 coffee growers. These plantations employ an average of around 659,865 people on a daily basis (IBEF, 2017). Wayanad is the largest producer of coffee in Kerala. The estimated production of coffee in during 2017-18 was given as 55,525 (MTs) that too from the production of Robusta alone and likewise in 18-19 it was 58,450(MTs) (Coffee Board, 2018).

Still there are many issues being faced by farmers in Wayanad. Price of the produce was not increased according to changes in cost of production. The Coffee Board held monopoly in procurement and sales of coffee, the cultivators did not get remunerative price. Fall in the price of coffee has forced many farmers to curtail or even to give up agricultural activities. As a result, large numbers of workers have been deprived of employment. Poverty is tending to become widen in the rural area of Wayanad, especially in Kaniyambetta panchayat as a consequence. Apart from the above situation, coffee growers in Wayanad district has been severely facing certain problems, including early blooming of coffee, out breaks diseases like black rot, berry dropping, mealy bug attack, climatic changes, and other problems like price volatility, inadequate storage etc. In addition to that, research studies have shown that coffee cultivators are reportedly switching away from coffee cultivation to other crops such as pepper and arecanut due to its un- remunerative nature. Marginal farmers showed more enthusiasm for shifting away from coffee to pepper. Besides this, the activities are done annually to rear, nurture, and maintain coffee plants in order to obtain the maximum possible yield from them has hiked the cost of production.

\section{Objective of the study}

To study the challenges faced by the coffee growers in Kaniyambetta panchayat of Wayanad district.

\section{Methodology}

The study was conducted in Kaniyambetta Panchayat of Wayanad district, during the month of January, 2020.To achieve the stated objective, primary data was mainly used. For substantiating the primary data, secondary data was collected from the reports of Coffee Board. Sixty respondents were selected for this study by purposive sampling and data was collected from the growers using structured interview schedule. Statistical tools like percentage analysis and index method were used for the analysis of data.

\section{Scope of Study}

The outcome of the study will be useful for the betterment of coffee growers, their production and productivity can be enhanced by analysing those problems of growers thus suggestions and recommendation can be made by the government and then formulate policy guidelines to solve those problems.

\section{Limitation of the Study}

Being a micro-level study confined to a village in a specific area, it may not have captured all the challenges faced by the coffee growers of the entire district. And time constrain was also considered as a limitation for the study. 


\section{Review of Literature}

Joy (2004) in his research study entitled as "Small growers of Sulthan Bathery, Wayanad studied the coffee industry in India and Kerala with the objectives of study the cost and return structure; Identification of the main determinants of yield; Examination of the relationship between farm size and farm efficiency; Investigation of the labour-absorption capacity of coffee on a comparative basis; Study of the extent of fluctuations in the price of coffee; Analysis of the effects of climatic changes on coffee yield; Examination of the incidence of pests and diseases and their effects on productivity. By using the Participatory Rural Appraisal (PRA) approach. And concluded that Small and marginal farmers practise mixed farming; they shift crops according to the charges in market conditions, particularly the price of coffee. When coffee prices fall, they reduce working expenses on coffee and shift to other crops especially to pepper. Distress sale of the product by small and marginal farmers is reported to be widely prevalent. Farmers sell the output well in advance of the harvesting season at prices much lower than those prevailing in the market in order to tide over their financial difficulties.

Rodrigues, (1999) studied the "Races of the pathogen and resistance to coffee rust" in which he described the economical, biological, physical aspects of coffee leaf rust including hyper parasitism of rust. The presence of an antifungal substance was indicated in the diffusates of leaves inoculated with an incompatible virulent race. He concluded that the substance was found capable of causing reduction in the spore germination and inhibition in germ tube length of the inoculated rust races by 40-50 percent, while, the diffusates of compatible combination did not exhibit significant influence on spore germination.

Murthy and Naidu (2011) in their study entitled "Improvement of Robusta Coffee Fermentation with Microbial Enzymes" highlights that Pectinase was produced by solid- state fermentation utilizing coffee pulp with Aspergillus Niger CFR 305. This is the first report on treatment of the pectinase produced by coffee pulp and application of the same on demucilage of coffee pulp indicating waste recycle with value addition and is also economical for coffee industry.

\section{Analysis}

The study entitled "Challenges faced by the coffee growers of Kaniyambetta panchayat of Wayanad district" has been carried out with the objective of identifying the problems faced by coffee growers. As a prelude to study the production and marketing problems of coffee growers, the socioeconomic profile of the growers were examined with the help of selected socio- economic variables such as age, gender, education, religion, caste, employment status, economic status, monthly income, family size, and source of income. It is analysed by percentage analysis. The socio-economic profiles of coffee growers are presented in the following table.

\subsection{Socio-economic profile of coffee growers}

Table. 1 Socio-economic profile of coffee growers

\begin{tabular}{|l|l|l|}
\hline Variables & Category & Total \\
\hline \multirow{4}{*}{ Age } & Up to 30 years & $0(0)$ \\
\cline { 2 - 3 } & $30-45$ & $10(16)$ \\
\cline { 2 - 3 } & $45-60$ & $31(53)$ \\
\cline { 2 - 3 } & Above 60 & $19(31)$ \\
\cline { 2 - 3 } & Total & $\mathbf{6 0}(\mathbf{1 0 0})$ \\
\hline
\end{tabular}




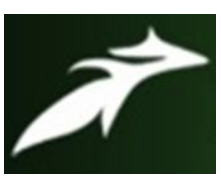

Niranjana Chandran et al, International Journal of Advances in Agricultural Science and Technology,

Vol.7 Issue.11, November-2020, pg. 145-156

ISSN: 2348-1358

Impact Factor: 6.057

NAAS Rating: 3.77

\begin{tabular}{|c|c|c|}
\hline \multirow{3}{*}{ Gender } & Male & $55(92)$ \\
\hline & Female & $5(8)$ \\
\hline & Total & $60(100)$ \\
\hline \multirow{5}{*}{ Education } & Primary & $15(25)$ \\
\hline & High School & $29(48)$ \\
\hline & Secondary & $13(22)$ \\
\hline & Graduation & $3(5)$ \\
\hline & Total & $60(100)$ \\
\hline \multirow{4}{*}{ Religion } & Hindu & $50(83)$ \\
\hline & Christian & $9(15)$ \\
\hline & Muslim & $1(2)$ \\
\hline & Total & $60(100)$ \\
\hline \multirow{5}{*}{ Caste } & SC & $6(10)$ \\
\hline & ST & $20(33)$ \\
\hline & OBC & $3(5)$ \\
\hline & GEN & $31(52)$ \\
\hline & Total & $60(100)$ \\
\hline \multirow{6}{*}{$\begin{array}{l}\text { Employment } \\
\text { status }\end{array}$} & Agriculture & $60(100)$ \\
\hline & Service & $6(10)$ \\
\hline & Business & $15(25)$ \\
\hline & Government & 1(2) \\
\hline & Private & $8(13)$ \\
\hline & Others & $1(2)$ \\
\hline \multirow{3}{*}{ Economic Status } & APL & $60(100)$ \\
\hline & BPL & 0 \\
\hline & Total & $60(100)$ \\
\hline \multirow{5}{*}{ Monthly Income } & $10000-15000$ & $34(57)$ \\
\hline & $15000-30000$ & $23(38)$ \\
\hline & $30000-45000$ & 0 \\
\hline & Above 45000 & $3(5)$ \\
\hline & Total & $60(100)$ \\
\hline \multirow{5}{*}{ Family Size } & Below 4 & $47(79)$ \\
\hline & 5 & $9(15)$ \\
\hline & 6 & $4(6)$ \\
\hline & Above 6 & 0 \\
\hline & Total & $60(100)$ \\
\hline \multirow{4}{*}{ Source of Income } & Agriculture & $60(100)$ \\
\hline & Wages & $9(15)$ \\
\hline & Profit & $15(25)$ \\
\hline & Salary & $8(13)$ \\
\hline
\end{tabular}

Note: Figures in the parentheses represents percentage to total

Source: Compiled from Primary data 
Niranjana Chandran et al, International Journal of Advances in Agricultural Science and Technology,

It is evident that the majority of the growers were in the age category of $45-60$ years (53 percent). Male growers are dominated in agriculture with 92 percent, only 8 percent are female. The education status of the respondents ranged from primary to post graduation. Majority of respondents had high school education (48 percent), followed by 25 percent of respondents had primary education and 22 percent of the growers had secondary education. The religion wise distribution revealed that Hindu community dominated in coffee cultivation than others. The caste wise cross section of the respondents revealed that majority of the growers of Kaniyambetta grama panchayat belonged to general category (52 percent). The employment status of the respondents revealed that all the respondents were engaged in agriculture and other than that they were engaged in business, service, government, private and others forms of work. The economic status of the respondent means whether they belonged APL category or BPL was ascertained from the ration cards of the growers. So it was evident from their monthly income that all growers were belonged to APL category. The study on the monthly income revealed that 57 percent of the growers had a monthly income of Rs.10000-15000 whereas, 38 percent of the respondents had monthly income of Rs.15000-30000. It was clear from the study that majirity (79 percent) of the growers had family size 4.

\subsection{Cultivation Practices}

The study examined the nature of cultivation practices adopted by the coffee growers of Kaniyambetta panchayat. Data was collected on variables such as area of coffee cultivated, years of coffee plant, varieties cultivated, weeding practices, pruning, bean collection, irrigation, insecticide, expenditure incurred for coffee cultivation and the collected data analysed by using percentage analysis method.

Table 2. Cultivation practices

\begin{tabular}{|c|c|c|}
\hline Variables & Category & Total \\
\hline \multirow{5}{*}{ Area of Coffee(acres) } & $1-3$ & $45(75)$ \\
\hline & $3-6$ & $12(20)$ \\
\hline & $6-9$ & 0 \\
\hline & $>10$ & $3(5)$ \\
\hline & Total & $60(100)$ \\
\hline \multirow{5}{*}{$\begin{array}{l}\text { Years of coffee } \\
\text { cultivated }\end{array}$} & $10-25$ & $5(8)$ \\
\hline & $25-50$ & $24(40)$ \\
\hline & 50-75 & $15(25)$ \\
\hline & $75-100$ & $16(27)$ \\
\hline & Total & $60(100)$ \\
\hline \multirow[t]{2}{*}{ Varieties of coffee } & Robusta & $60(100)$ \\
\hline & $\mathbf{C} * \mathbf{R}$ & $2(3)$ \\
\hline \multirow{5}{*}{$\begin{array}{l}\text { Weeding } \\
\text { (times/year) }\end{array}$} & Once & $\mathbf{0}$ \\
\hline & Twice & 47(70) \\
\hline & Thrice & $12(28)$ \\
\hline & Four times & $1(2)$ \\
\hline & Total & $60(100)$ \\
\hline
\end{tabular}




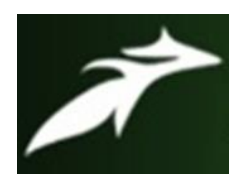

Niranjana Chandran et al, International Journal of Advances in Agricultural Science and Technology,

Vol.7 Issue.11, November-2020, pg. 145-156

ISSN: 2348-1358

Impact Factor: 6.057

NAAS Rating: 3.77

\begin{tabular}{|c|c|c|}
\hline \multirow{5}{*}{$\begin{array}{l}\text { Pruning } \\
\text { (times/year) }\end{array}$} & Once & 1(2) \\
\hline & Twice & 44(73) \\
\hline & Thrice & $13(22)$ \\
\hline & Four times & $2(3)$ \\
\hline & Total & $60(100)$ \\
\hline \multirow{3}{*}{ Bean Collection } & Hand picking & $60(100)$ \\
\hline & Mechanically & $\mathbf{0}$ \\
\hline & Total & $60(100)$ \\
\hline \multirow{4}{*}{ Irrigation } & Rainfed & $48(80)$ \\
\hline & Springler & $9(15)$ \\
\hline & Ooze & $3(5)$ \\
\hline & Total & $60(100)$ \\
\hline \multirow{5}{*}{$\begin{array}{l}\text { Expenditure (in } \\
\text { thousands) }\end{array}$} & $25-50$ & $13(22)$ \\
\hline & 50-75 & 12(20) \\
\hline & $75-1$ & 14(23) \\
\hline & $>1$ & 21(35) \\
\hline & Total & $60(100)$ \\
\hline
\end{tabular}

Note: Figures in the parentheses represents percentage to total

Source: Compiled from Primary data

It is clear that majority of growers had the area of Coffee between 1-3 acres (75 percent), followed by 20 percent of growers who had area more than 10 acres. The majority were small and marginal growers with landholding less than 2 hectares. The years of cultivation of coffee revealed that 40 percent of coffee was planted in between 25- 50 years. 27 percent of coffee was planted between 75100 years. And followed by 25 percent with 50-75 years of age of coffee cultivation. Only 8 percent of coffee had the age of cultivation of 10-25 years. There were two varieties of coffee in Kaniyambetta panchayat ie, Coffee robusta and $\mathrm{C} * \mathrm{R}$ (Congensis * Robusta). It is clear from the table that 100 percent of growers were growing coffee robusta and 3 percent grow $C^{*} \mathrm{R}$ along with robusta.

It is clear that majority of growers are doing weeding annually. 70 percent of the growers are doing weeding twice a year, 28 percent are doing weeding for thrice and 2 percent are doing weeding for 4 times. Pruning is done by growers annually, while 73 percent do it twice a year. 22 percent of growers do it thrice a year and only 3 percent is do it for four times. All growers are collecting beans through hand picking. There is no mechanical harvester used in the panchayat. For irrigation 80 percent of the growers depend on rain, whereas 15 percent of the growers use springler irrigation. And only 5 percent are using ooze for irrigation. None of the growers are applying any insecticide for coffee.

Major challenge in coffee production is the expenditure incurred. Here the table shows that 22 percent of growers incures expense of more than 1 lakh rupees. 23 percent of the grower's incurs expenditure of above Rs 75,000. 22 percent of respondents have the expense of Rs 25,000 to 50,000 and 20 percent incures Rs 50000-75000. 


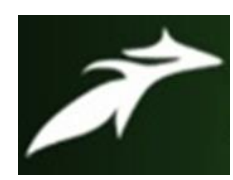

Niranjana Chandran et al, International Journal of Advances in Agricultural Science and Technology,

Vol.7 Issue.11, November-2020, pg. 145-156

ISSN: 2348-1358

Impact Factor: 6.057

NAAS Rating: 3.77

\subsection{Challenges faced by Coffee Growers}

In order to analyse the objective the problem statements were subdivide into 3 heads viz., production problem, harvesting problem and marketing problem. The analysis was carried out using percentage analysis and index method and the following scale was adopted to draw conclusions on the various parameters under study.

\section{Classification of Problems}

\begin{tabular}{|l|l|l|}
\hline Index obtained & Problems/challenges category & \\
\hline $0-20$ & Negligible & \\
\hline $21-40$ & Tolerable & \\
\hline $41-60$ & Risk & \\
\hline $61-80$ & Severe & \\
\hline $81-100$ & Chronic & \\
\hline
\end{tabular}

\subsubsection{Production related problems of coffee growers}

Coffee cultivation is dealing with a lot of production problems. Production problems were the major constrain faced by the growers. For the purpose of analysis the problems are categorised into 18 statements. Here these statements are analysed through Index analysis and rank order is given according to index.

Table. 3. Production related problems of coffee growers

\begin{tabular}{|c|l|c|l|l|}
\hline $\begin{array}{r}\text { Sl } \\
\text { no. }\end{array}$ & \multicolumn{1}{|c|}{ Statements } & Score & Index & \\
\hline 1 & Attack of pest and diseases & 297 & 99 & Chronic \\
\hline 2 & Lack of management for diseases & 289 & 96 & Chronic \\
\hline 3 & Climatic changes and natural calamities & 299 & 100 & Chronic \\
\hline 4 & Early blooming due to irregular rainfall & 299 & 100 & Chronic \\
\hline 5 & Lack of availability of quality inputs & 293 & 98 & Chronic \\
\hline 6 & Lack of Irrigation & 272 & 91 & Chronic \\
\hline 7 & Lack of pruning & 272 & 91 & Chronic \\
\hline 8 & High initial cost of cultivation & 278 & 93 & Chronic \\
\hline 9 & High cost of weeding & 273 & 91 & Chronic \\
\hline 10 & Shifting cultivation from coffee & 77 & 26 & Tolerable \\
\hline 11 & Reduction in the area of coffee & 95 & 32 & Tolerable \\
\hline & Composite Index & $\mathbf{2 7 4 4}$ & $\mathbf{9 5}$ & Chronic \\
\hline
\end{tabular}

Source: Compiled from Primary data.

It was observed that majority of the mentioned problems had fallen in the category of 81-100, which says that the problems are "chronic". It was understood from the opinion of respondents that growers are struggling with the fluctuating climatic changes. Irregular rainfall of last year declined the production of coffee drastically (Coffee board, 2018). Likewise early blooming was another major 


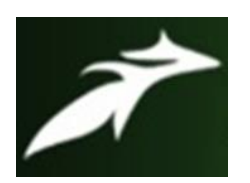

Niranjana Chandran et al, International Journal of Advances in Agricultural Science and Technology,

Vol.7 Issue.11, November-2020, pg. 145-156

ISSN: 2348-1358

Impact Factor: 6.057

NAAS Rating: 3.77

problem observed. It is observed that robusta is major variety of coffee cultivated in Wayanad, it is cultivated in between December and late March. The coffee plant requires its first shower by February last or early March and its second shower must be one week after the first shower. So it will provide time for the blooming of coffee. And after one week the second shower should be provided, it will be helpful for the bean growth and maturity. One week should be provided for blooming, after the dropping of flowers only second shower is given. But last year 2018-19 due to the irregular rainfall second shower came soon and resulted with the destruction of everything. So the production of coffee is tremendously reduced in that year.

According to the table one of the major problem is disease and pest attack. It is observed that heavy rainfall resulted in the outbreak of diseases like black rot, berry dropping, leaf rust, and pest attack includes berry borer, mealy bug, shot hole borer etc. The seasonal variations triggered with different kinds of diseases which in turn resulted in heavy crop loss. There are no measures taken by the growers to avert the diseases.

Another production problem is lack of quality inputs. According to the information from growers they were unable to have quality inputs for the production. The assistance from coffee board is restricted in the supply of inputs for the growers. Now a days the growers are purchasing the inputs like seedlings, fertilizer, pesticides etc from the private shops by paying high prices. The expenses incurred by the growers on purchasing the inputs for cultivation is higher than that of return he gained from the production.

It is evident that lack of irrigation leads to destruction of the entire plant. Here the respondents opinioned that there is no timely showers. Due to the irregular rainfalls the production will be declined. As coffee is a water-sensitive crop and it needs sufficient quantity of water for getting the expected quantities of yield. The first blossom showers are important for the timely flowering of coffee plants. Showers should be provide at least thrice a year. For the complete activities in coffee growth water is an essential factor. The dependence on rainfall makes coffee cultivation a gambling with nature and growers get proper yield only if blossom showers are there in adequate quantity and in proper time. If the rain is received late, the production and productively levels are adversely affected. So lack of irrigation will adversely affect the growth of coffee.

It is observed that the problems regarding reduction of area under cultivation is fell under the category 21-40 and is a "tolerable" problem. Only a few of the growers reduced their area under coffee cultivation. It is because of the income from the coffee is less than that of other crops. They opinioned that coffee cultivation is unremunerative in nature. So that the growers shift their cultivation to some other crops like pepper, arecanut. Cropping pattern shifts were mostly from coffee to pepper.

\subsubsection{Types of pest and diseases affected in coffee.}

The major problem which affected the coffee production is the disease attack. The high incidence of insect and pest is prevalence for disease. Some kinds of pests destruct the entire plants while some other pest affect only the fruit-bearing capacity of the plants and thus reduce their production of berries. The growers reported that the following diseases, pests, and insects mainly affect coffee plants. 


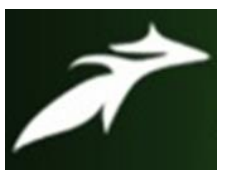

Niranjana Chandran et al, International Journal of Advances in Agricultural Science and Technology,

Vol.7 Issue.11, November-2020, pg. 145-156

Table 4. Diseases and pest affected

\begin{tabular}{|l|c|}
\hline Diseases & Total \\
\hline Berry borer & $57(95)$ \\
\hline Mealy bug & $46(77)$ \\
\hline Black rot & $32(53)$ \\
\hline Berry dropping & $29(48)$ \\
\hline Stem borer & $24(40)$ \\
\hline
\end{tabular}

Note: Figures in the parenthesis represents percentage to total Source: Compiled from

Primary data

From the table it is observed that 95 percent of the respondent opinioned that coffee was affected with berry borer attack. Berry borer attacks coffee during the stage of berry development to ripening of berries. After making a circular hole borer enter into the hole of the coffee berry and then it deposit eggs within the berry, followed by larval feeding on the coffee seed. This reduces the yield and quality of coffee, which in turn affects the income of coffee growers.

Another serious pest of coffee is mealy bug, it is clear that 77 percent respondent reported that there is attack of mealy bug in Coffee. Mealy bug attack both Arabica coffee and robusta. It is the white coloured masses of bugs, it can be seen on upper side of leaves, berries, and flower buds or on sucker tips. After the infestation plants shed their leaves. By the heavy infestation the entire plant will be die. It is 53 percent growers opinioned that coffee is affected by black rot disease. Black rot is the pathogen affect the developing berries and young shoot. There will be black rotting symptoms and strikes on the infected parts. After the infestation there will infestation and berry dropping. There is 8 percent of berry dropping reported in the study area. There will necrosis and black spot on berries and finally the premature berries will be dropped.

The table shows that 40 percent of respondent is opinioned that there is stem borer attack. It is a blackish brown coloured beetle measuring about $2 \mathrm{~cm}$ in size. The larve enters the hard wood burrows up to the roots. Infested plants show yellowing and wilting of leaves, presence of ridges on the stem, wilting of branches and finally drying of plants.

\subsubsection{Harvesting related problems of coffee.}

There many issues faced by the growers in harvesting coffee. Here the problems are collected from the opinion of growers. For the purpose of analysing it is categorised into six statements and analysed by index method.

Table 5. Harvesting related problems of coffee growers.

\begin{tabular}{|l|l|l|l|l|}
\hline $\begin{array}{l}\text { Sl } \\
\text { no } \\
\text { - }\end{array}$ & \multicolumn{1}{|c|}{ Statements } & Score & Index & \\
\hline 1 & Lack of maintenance of coffee beans & 278 & 93 & Chronic \\
\hline 2 & High maintenance cost & 267 & 89 & Chronic \\
\hline 3 & Less income than cost of cultivation & 299 & 100 & Chronic \\
\hline
\end{tabular}




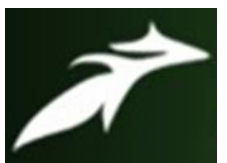

Niranjana Chandran et al, International Journal of Advances in Agricultural Science and Technology, Vol.7 Issue.11, November-2020, pg. 145-156

\begin{tabular}{|l|l|l|l|l|}
\hline 4 & Lack of labour supply & 300 & 100 & Chronic \\
\hline 5 & High wages of labourers & 299 & 100 & Chronic \\
\hline 6 & $\begin{array}{l}\text { Changing wages affects cost of } \\
\text { Production }\end{array}$ & 298 & 99 & Chronic \\
\hline & \multicolumn{1}{|c|}{ Composite Index } & $\mathbf{1 7 4 1}$ & $\mathbf{9 7}$ & \\
\hline
\end{tabular}

Source: Compiled from Primary data

The statements here mentioned are "chronic" problems, which includes labour supply issue with index 100. Coffee sector provide large scale employment to the people of Wayanad. Mainly the tribal folk depend on coffee cultivation for their livelihood. Coffee provides work for all seasons. It is estimated from the table that labours are migrating to some other works like MGNREGA, construction etc. And labourers are demanding huge wages; due to the lack of production the growers couldn't afford the increasing wage structure. 90 percent of the total expenditure of coffee was incurred as wages. It was observed that the youth of today is unwilling to do manual labour and work on the coffee garden even though they are unemployed. So lack of labour supply is a dominant issue in coffee industry.

From the table it is clear that lack of maintenance in coffee will be a big challenge for the growers. It is observed that maintenance of coffee is a difficult task, it requires labour supply, proper inputs availability, skills for maintenance etc. All the farming activities are comes under maintenance. Disease management is essential in coffee cultivation. But the growers were unaware of the maintenance on diseases and pest attack. The agricultural operations in coffee are seasonal proper care should be provided in all seasons otherwise there will be huge crop loss for the growers. Coffee is procured by private dealers hence they give greater emphasis on the quality of coffee, so lack of maintenance will reduce the quality of coffee thus the price of the produce will be reduced. So lack maintenance affect the quality of coffee and also the problems regarding the initial cost. Coffee will give yield from the fourth year of Planting. After planting constant care should be done for four years to ensure their healthy growth. The cost involved in planting coffee seedlings and the expenses incurred for all the agricultural operations till they reach the fruitbearing stage comprise the initial cost. It will be very high so the investment will be higher than the return from coffee.

\subsubsection{Marketing related problems.}

Coffee industry is facing many marketing problems. Here marketing related issues are collected from the respondents through 8 statements. It is analysed through Index analysis and ranked according to the severity of problems.

Table 6. Marketing related problems

\begin{tabular}{|c|l|c|c|c|}
\hline $\begin{array}{c}\text { Sl } \\
\text { no }\end{array}$ & \multicolumn{1}{|c|}{ Statements } & Score & Index & \\
\hline 1 & Growers do not get stable price for their produce & 298 & 99 & Chronic \\
\hline 2 & Private dealers exploit the small growers & 112 & 37 & Tolerable \\
\hline 3 & Volatility in market cost & 299 & 100 & Chronic \\
\hline 4 & Delay in payment & 109 & 36 & Tolerable \\
\hline
\end{tabular}




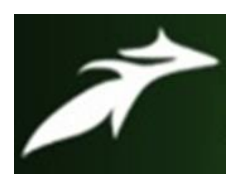

Niranjana Chandran et al, International Journal of Advances in Agricultural Science and Technology, Vol.7 Issue.11, November-2020, pg. 145-156

ISSN: 2348-1358

Impact Factor: 6.057

NAAS Rating: 3.77

\begin{tabular}{|l|l|l|l|l|}
\hline 5 & Excessive emphasis upon quality & 281 & 94 & Chronic \\
\hline 6 & Lack of storage facility & 288 & 96 & Chronic \\
\hline 7 & No proper marketing channel & 295 & 98 & Chronic \\
\hline 8 & Lack of processing and grading facilities & 295 & 98 & Chronic \\
\hline & Composite Index & & & \\
& 1978 & & \\
\hline
\end{tabular}

Source: Compiled from Primary data

According to the research report of IBEF 2017, coffee market in India is unstable. It is observed from the table that the problem faced by the coffee growers are volatility in market price which is fell under category of 81-100 and it is ,chronice with index 100. The 2018 report of Coffee board showed that the price of robusta coffee for the past 10 years was in between Rs 30-65, now it is Rs 63. It changes according to changes in the world's market. Due to the instability in the global market the growers are unable to get favourable price for their produce. Hence the problem with index 99. According to global trend in price, the price of inputs are increasing drastically but still the market price for coffee is unstable. The coffee price is remained stagnant for a long period. Price of the produce was not increased according to changes in cost of production. In the past years Coffee was directly procured by the Coffee Board, according to the opinion of respondents Coffee Board had a monopoly in procurement of coffee the growers were unable to get reasonable price hence they sell the produce through private dealers.

It is observed that the other major problem in coffee is lack of proper marketing channel and it is in the category 81-100, which is "chronic" with index 98. It is identified that growers are marketing their produce through private dealers. The main player in marketing channel is the producer, they are the growers of coffee. Second one is the local traders who procure coffee from the growers, the others are undertaking curing, roasting, packing, branding etc. There are persons involved in exporting of coffee. Growers are getting their price through the private dealers according to the quality of produce.

Another problem is lack of grading and processing of coffee which is a "chronic" problem with index 98. It is observed that majority of the growers are selling their produce in sun dried form. They are unable to do grading and processing of coffee. Insufficient knowledge on proper harvesting, drying, and storage of coffee beans is recorded a problem. And also there is no enough space or drying yard for coffee.

It is evident that the market cost for the produce is fluctuating. It is rated as "chronic" fell under the category of 81-100. The global market price of coffee is volatile. Report shows that market price for the past years are lowering. Growers are storing their produce and while the market price is favourable they sell the produce.

Lack of storage facility for coffee is a "chronic" problem which fell under the category of 81-100. The unavailability of storage in their area is a problem faced by the growers. Most of the growers are storing their produce in their house itself. Coffee beans are collected in the sacks and it should be properly stored in a dry, ventilated and rain proof areas until sale. There is no such areas for coffee storage. It will reduce the quality and quantity of produce through pest and rodents attack.

The issue related with emphasis on quality of coffee is a "chronic" problem with index 95 . The coffee is 


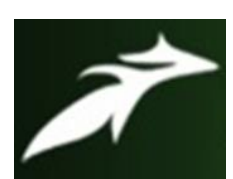

Niranjana Chandran et al, International Journal of Advances in Agricultural Science and Technology,

Vol.7 Issue.11, November-2020, pg. 145-156

ISSN: 2348-1358

Impact Factor: 6.057

NAAS Rating: 3.77

procured by the private dealers, they are mainly collecting the coffee for exporting purpose or branding. Hence they give more emphasis on the quality of produce. Quality will be analysed through shape, colour, weight, bean quality etc, other coffee will be refused. Thus the price is determined by them.

Private dealers collect coffee from the growers and price will be charged by them. But in the past Coffee board procured coffee and price is given to the growers. Now the private dealers are fixing the price by analysing the market cost. So there will not be much delay in the payment for the growers. These statements were under the category of $21-40$, which is "tolerable" and according to the intensity it is with index $36-37$. The respondents opinioned that growers will get reasonable price than from the Coffee board.

\section{Conclusion}

The objective of the research was to study the challenges faced by coffee growers of Kaniyambetta grama panchayat and to study the extend of institutional assistance provided to the coffee growers. From the study it was concluded that the coffee growers in Kaniyambetta panchayat is facing many problems related to the coffee cultivation. The majority of the farmers are small and marginal were not affordable to maintain the agricultural operations in coffee. The prices of the inputs are costlier than that of the cost of production. Fall in the price of coffee forced many farmers to curtail or even to end up agricultural the activities The present circumstance of coffee includes rapidly changing weather condition, proliferation of pest and diseases etc. resulted with declined production of coffee. Other than the production issues, under marketing problems are also evident in coffee industry. There is no proper marketing channel for coffee. Coffee industry is also devoid of institutional assistance. In overall view coffee industry of Wayanad is in recession.

\section{References}

[1]. Joy, C.V. 2004. Small growers of Sulthan Bathery, Wayanad. Kerala Research Programme on Local Level Development, Thiruvanantapuram, 37p.

[2]. Rodrigues, C. J.1999. Races of the pathogen and resistance to coffee rust. Annual Review of Phytopathogen. 13(1):49-51.

[3]. Murthy and Naidu. M .2011. Improvement of Robusta Coffee Fermentation with Microbial Enzymes. European journal of applied sciences. 3(1):7-10.

[4]. ICO [International Coffee Organisation].2018.ICO Coffee Market Report: An overview [on line]. Available: http://www.ico.org/ [2 February,2018].

[5]. Coffee Board.2018. Annual report 2017-18. Government of India, Ministry of commerce \& industry.[on line]. Available: https://www.indiacoffee.org/ [December, 2018].

[6]. India micro finance.2017. Report on coffee market.[on line].Available: https://indiamicrofinance.com/ [23 January, 2017].

[7]. IBEF [International Brand Equity Foundation].2016.IBEF Indian Agricultural Industry: An overview [on line]. Available: https://www.ibef.org/ [22 December. 2016]. 